OPEN ACCESS

Edited by:

Shaun Murphy,

University of Saskatchewan, Canada

Reviewed by:

Sonia Houle,

University of Alberta, Canada

Lynne Driedger-Enns,

Brandon University, Canada

*Correspondence:

Donna L. Brown

donna.brown@epsb.ca

Specialty section:

This article was submitted to Assessment, Testing and Applied

Measurement,

a section of the journal

Frontiers in Frontiers in Education

Received: 24 April 2021

Accepted: 26 October 2021

Published: 21 February 2022

Citation:

Brown DL (2022) Tree Stories: Assessment Making as Relationally Respecting, Dynamically Listening with

Care, and Inviting

Celebratory Journeying.

Front. Educ. 6:699885.

doi: 10.3389/feduc.2021.699885

\section{Tree Stories: Assessment Making as Relationally Respecting, Dynamically Listening with Care, and Inviting Celebratory Journeying}

\author{
Donna L. Brown* \\ Edmonton Public Schools, Edmonton, AB, Canada
}

Through my recent Master of Education journey, I am becoming increasingly awake to the ways in which I value "place" when thinking of my autobiographical beginnings, teaching, learning, and assessment making alongside children. As a forest and nature kindergarten teacher in a $\mathrm{K}-6$ elementary school, who is facing increasing class sizes, classroom complexity, parental anxieties, and children's wide-awakeness to all these influences, I worry about early childhood development and the knowing that each of us, from an early age, holds embodied experiences which guide us and either nurture or hinder our development. I see the importance of co-creating environments to invite children, parents, and educators to think collaboratively, and emergently to come to learning and knowing and assessment making. Basso (1996) writes, "relationships to places are lived most often in the company of other people, and it is on these communal occasions - when places are sensed together - that native views of the physical world become accessible to strangers" (p. 109). We teach and learn in social contexts across time and in the world of formal education on landscapes called schools. However, my hope is for schools to be thought of in a broader context, which bends and sways as we ground ourselves in experiential pedagogies (Dewey, 1938). Pedagogies which are always in the midst and in the making. Narrative beginnings matter. With this thinking, we become awake to knowing that our collective approaches to the education of young children will significantly affect future leaders and the environment which sustains us. My current research puzzling for the purpose of this special issue is as follows: in what ways can landbased, place-based, emergent, and playful experiential learning approaches in school outdoor settings increase child, family, and teacher collaboration? What role might assessment making have in this collaboration and the child's learning? Do the stories that children come to live and tell through this collaboration and their dynamic interaction with one another, their families and teachers, and more-than-human beings influence the lives they are making in the present in their early years of schooling i.e., $\mathrm{K}-3$, and into their futures?

Keywords: assessment making, co-curriculum making, place-based learning, land-based teaching, emergent curriculum, experiential learning, life-making, narrative inquiry 


\section{BEGINNING WITH THREE TEACHING MOMENTS}

"Mrs. Brown, Mrs. Brown, Mrs. Brown," we hear in the distance as educators, children and families gather in our school field. But where is it coming from, we wonder? The call repeats. I travel towards the voice and look up to the highest branches that might be stable enough to hold a four-year-old. I wonder-how did this child get there? Are her parents close by? Why did she leave the group? How long has she been there? Will she hurt herself? What will my response be? How can I stay present, encouraging, and ready to listen to the next part of her call? I arrive at the bottom of the Scots Pine tree and as I gaze up through the branches, I spot a smiling face. No words come from her tiny perch, but she speaks louder than I could ever imagine through her expressive, joy-filled fix on my eyes. A bird's eye view! How lucky and how free and how brave she is. I imagine what it might feel like as I move closer to inquire, alongside ... (September 2020 Personal Journal Entry, Tree Story Part One)

"You should see what I see!" we hear a voice announce with elation. As we gaze upward, we can barely glimpse his feet. We move closer, under the Ponderosa Pine, until we are nose-to-nose with the needles, cones and within range of our climbing friend-in case he has more to say. We count the needles in each bundle. We study the texture of the cones as they present themselves from sticky to bumpy to poky. We smell needles, cones, the ground, the sky, each other, and we giggle. We wonder about how the Ponderosa got its name. We research, collectively creating theories to be considered and to further wonder with. Is this cone the same as the cones from the neighboring Scots Pine? Is this cone the same or different from Spruce Tree cones? What about Tamarac Trees to the West of our field? Do the Tamarac Trees, with their soft needles that we love so much, have cones? We run to find out! (November 2020 Personal Journal Entry, Tree Story Part Two)

During the Covid-19 Pandemic, with school shifted to "at home learning," a parent sends me a message. The online assignment is to engage in a sit-spot in nature. She shares that her whole family participated: her husband, daughter, and son. Her son, who is in kindergarten, invited them to "his tree hangout spot" to engage in this experience. I pause and wonder about what tree she might be referring to. I think back to when I was alongside this child during inperson learning. He was the child who did not want to climb trees because, he said, he was afraid of heights. His Mom shares a photo of her son climbing up into "his tree." She scribes his words for the assignment that invites him to use his senses: "I see grass, moss, branches and needles. . I smell fresh air from the rain ... and hear birds." When asked how the place feels, he replies, "comfy!" (June 2021 Personal Journal Entry, Tree Story Part Three).
These moments unfolded alongside kindergarten children during a year of teaching and learning. Inspired by my own personal experiences of being outside in nature, I think deeply with moments like these as part of my teaching practice. The collective stories of children and teachers-our shared narratives-invite relationship, experiential connection, and creative possibility as we learn and grow together. These are a few of many moments that encourage me to wonder about the multiplicity of ways of knowing that nature and time on the land invites. This wondering, alongside my genuine excitement and eager anticipation that is shared through dialogue within a school community, makes me consider how these types of moments might lead to assessment making (Murphy et al., 2012). Creatively playing with the idea of assessment, storied knowing can invite and lead educators to reflectively consider curriculum as an animated life-making process. This emergent programming that moves with children's passions and interests is dynamic and exhilarating in nature. When educators approach each day with awe, wonder, and anticipation for what could and what might be, there is hope that children will see themselves as active participants in teaching, learning, and assessment that is co-created and always in the making.

\section{NARRATIVE BEGINNINGS MATTER}

Through my recent Master of Education (2020) journey, I am becoming increasingly awake to the ways in which I value place when thinking of my autobiographical beginnings, teaching, learning, and assessment making (Clandinin et al., 2011) alongside children. As a forest and nature kindergarten teacher in a K-6 elementary school, who is facing increasing class sizes, classroom complexity, parental anxieties, and children's wideawakeness to all these influences, I worry about early childhood development and the knowing that each of us, from an early age, holds embodied experiences which guide us and either nurture or hinder our development. I see the importance of co-creating environments to invite children, parents, and educators to think collaboratively, collectively, and emergently to come to learning and knowing and assessment making. I find this praxis, which is always becoming and evolving as we navigate uncertainty, to be vital in the troubling times we are facing together. Basso (1996) writes, "relationships to places are lived most often in the company of other people, and it is on these communal occasions-when places are sensed together-that native views of the physical world become accessible to strangers" (p. 109). We teach and learn in social contexts across time and in the world of formal education on landscapes called schools. However, my hope is for schools to be thought of in a broader context, which bends and sways as we ground ourselves in experiential pedagogies (Dewey, 1938). Pedagogies which are always in the midst and in the making. Narrative beginnings matter. With this thinking, we become awake to knowing that our collective approaches to the education of young children will significantly affect future leaders and the environment which sustains us. My current research puzzling for the purpose of this special issue is as follows: in what ways can land-based, place-based, emergent, and playful 
experiential learning approaches in school outdoor settings increase child, family, and teacher collaboration? What role might assessment making have in this collaboration and the child's learning? Do the stories that children come to live and tell through this collaboration and their dynamic interaction with one another, their families and teachers, and more-than-human beings influence the lives they are making in the present in their early years of schooling i.e., $\mathrm{K}-3$, and into their futures?

As I think with my journal entries-Tree Story in three parts-from my most recent year of teaching and learning, I find myself dreaming about our collective and communal becoming at school, with an ever-present seeking to stay mindful to all that is around us. When teaching outside, alongside four, five, and six-year-old children and an inspiring team of educators, I am filled with gratitude and joy each-andevery day. It is moments like these, learning by playing and discovering among and with the trees, that help me to become increasingly awake to who I am and who I am becoming as an educator. Throughout these experiences, I find myself continually wondering about ways to represent children's knowing and learning; representations that the children experience as empowering and that makes visible this intentional process with children, their families, and educators alongside.

As this article unfolds, I show my forward, backward, inward, and outward thinking and place connections (Clandinin, 2013), which I understand as a reflective form of assessment making that holds central for me, questions of my living in relationally ethical ways (Clandinin et al., 2018). I invite you to linger alongside me as I consider the emerging assessment making spaces that the forest invites and as I locate the possibilities in positionality we hold as educators.

\section{THINKING WITH NARRATIVE INQUIRY}

As I engage in narrative inquiry, as both phenomenon and methodology (Connelly and Clandinin, 2006; Clandinin 2013), and as pedagogy (Huber et al., 2013; Cardinal and Fenichel, 2017), I think narratively with the three common places of Narrative Inquiry: place, temporality, and sociality (Connelly and Clandinin, 2006; Clandinin, 2013).

Nxumalo (2015), whose interests revolve around pedagogical possibilities while reconceptualizing and resituating place-based and environmental education in early childhood environments, guides me to consider "seeing place as neither simply physical nor easily categorized but rather as a place of complex mutual encounters" (p. 29). With this emerging awareness and sensitivity, I am reminded of Noddings' (1986) ethic of care and fidelity in education. Noddings suggests that in "an ethic of caring-fidelity is not seen as faithfulness to duty or principle but as a direct response to individuals with whom one is in relation" (p. 497). Both Noddings and Nxumalo's thoughts help me to attend to relationships with "an ethic of "responsive attentiveness" to everyday encounters and complexities, relationalities and tensions they bring into view" (Nxumalo, 2015 , p. 23). As I am considering this awakeness to tensions and the value of being in relation to those I am alongside, Caine and Steeves (2009) ground me and remind me of "how difficult it is to stay in relation" (p. 1). As an educator, it is vital for me to stay awake and accountable to the challenges that present themselves and to consider my stories that guide and shape who I am and who I am becoming. To stay awake, I imagine the metaphor of a landscape that is full of bumps, turns, and valleys to help me to soften my gaze. I strive to use my peripheral vision as Mary Catherine Bateson (1994) might suggest, as well as my imagination, as Maxine Greene (1995) might guide me, to embrace the young learners with whom I am in relation with openness and active, mindful listening.

To express what I am coming to know, as well as thinking through the lens of narrative inquiry, I choose to embrace experience as "happen (ing) narratively" (Clandinin and Connelly, 2000, p. 19) and I am honouring "narrative inquiry (as) a way of understanding experience" (p. 20). This embodiment of narrative inquiry encourages me to stay present and embrace ideas of always intentionally being in the midst of learning ${ }^{1}$. This way of being inspires me to understand that I am always becoming as a person in the world, continually and purposefully inquiring into teaching and learning as a relational endeavor.

Through my ongoing learning, I see that the more I tell stories and the more I wander with them, the more I am awakened to possibility when considering the storied moments that matter. These stories help me reflect on my own narrative beginnings and my current work as a narrative inquirer. As I think with a few of my own storied life-making moments, which make up my personal practical knowledge (Clandinin, 2013), I am inspired by Maxine Greene as she suggests the idea that we can "invent our narratives" and thus "determine the direction of our lives" and the notion that we can understand our lives as a "quest" (Greene, 1995, p.75). I am reassured by her knowledge that "Seeing our lives as quests opens the way to our also seeing them in terms of process and possibilities" (Greene, 1995, p.75). Greene's sense of "imagination" is vital and alive. It connects me with the world of being alongside children. It pushes me to listen to and foster their imaginations, as well as my own. However, as Greene also posits, "the role of imagination is not to resolve, not to point the way, not to improve. It is to awaken, to disclose the ordinarily unseen, unheard, and unexpected" (Greene, 1995, p.28).

\section{FORWARD, BACKWARD, INWARD, OUTWARD, AND PLACE CONNECTIONS}

As I inquire into my Tree Story Journal Entries, I consider the past, present and future as a cyclical movement highlighting people, places, things, and events. Through Part One of the story, I wonder about the young girl and her bravery, independence,

${ }^{1}$ Clandinin (2013) suggests that narrative inquiry occurs when we are in the midst of lives. For me, it is living alongside institutional narratives (large school division following provincially mandated curriculum) which shapes my attending to "past, present, and future unfolding social, cultural, institutional, linguistic, and familial narratives" (p.43). 
and ability as it relates to who she is and who she is becoming on her home landscape. How has she grown upon the land? I am drawn to ask her parents if they live in close proximity to many trees and if they personally feel a connection with the natural world? As I ask the young girl, she tells me that she has lots of trees and animals where she lives. Together, we chat about the tree she is climbing. We discuss how much love and care she shows the tree as she carefully navigates climbing up and down the branches. As I listen to her tell me about the land where she lives, I share about a tree where I live that I think she might love. I describe the light orange bark that flakes off when a squirrel balances to reach a pine cone out on a limb. Through our sharing exchange, I wonder with her about how she might be able to reach a branch on a tree that is taller than her, like the one in my backyard. She leads me to a tree and scales it with the efficiency of a porcupine! Looking up at her small face peeking through the branches, I suggest we document her climbing this school year. A photograph of her in every tree that she climbs. She asks me if I can share the photos with her parents; I do and dialogue blossoms, relationality blooms! As I imagine the future, inquiring into this story with my co-educators, we wonder about inviting other children to climb, observe, and wonder together with us about the trees and climbing and being on the land. We talk about all of the animals who love trees. We imagine, share thoughts, hypotheticals ... stories. This leads us to the concept of perspective. When these creatures peer out from the high branches, what do they see?

When Tree Story Part Two emerges, we are a few months into the school year, and a young boy, often too busy running and moving, is now up a tree and exclaiming his elation at what he notices. We wonder if perhaps he has observed his peer, on her photographic journey of the trees she climbs, and is inspired to explore in her footsteps. We also wonder if he just stumbled upon the opportunity and before he knew it, he was up a tree. He shares that he had never climbed a tree before. We ask him to describe what he is seeing at that very moment. He tells us about many nature beings he sees: birds, trees, sky and he notices our school as well. Looking forward, we wonder about whether or not he will continue to climb trees. Might he seek them out? Might he crave their perspective? Might he share his climbing with others? Will he look at the trees near where he lives in a new way?

Collectively, as a class community, we decide to read the story All the Places to Love by Patricia MacLachlan (1994). Thinking together, children and educators alike sit in a circle and pass around a talking stick to encourage each other to listen and pause within the storied places. Trees, hills, creeks, and forests fill the circle and before we know it, there are familial connections being shared. Hopes and dreams and feelings are emerging. As one person listens to the next, it is clear that deep attending to each other's stories is occurring and children are revising and shaping their ideas, thoughts, and preferences by building on to what another has said. Thoughts build upon thoughts and as we honour each other's thinking, we move forward.

As we build curriculum around our stories, co-creating and co-planning forward, we begin to pack our backpacks and wagons to bring along what we need to be in dialogue with the children who are sharing their places to love, with vulnerability and passion. We pack and prepare for each day ahead with openended possibilities and strong connections to passions, interests, and wonders! We make a Bird Place invitation with binoculars, maps, bird books, tree books, a blanket, paints, paper, scissors, string and burlap; we make a Penguin Place invitation with sleds, pylons and signs for up and down with arrows for children to organize to keep safe on any hills we might encounter; we make a Bear Place invitation with bear story books, stage curtains on ropes to string from trees, forest animal masks, musical instruments; we make a Mud/Snow Kitchen with pots and pans, spoons and ladles, colanders and sieves, to prepare food in case we are hungry as we travel; we make a Coyote Place with animal track and animal scat books, magnifying glasses, study jars, ropes for balancing, a parachute for running with, and rings for swinging and leaping from. These places, played upon and grown through storytelling, nurture our collaborative interaction with a constant reaching for knowing and being in relation.

As we travel through our well-loved places across the winter, we bring our backpacks and sleds, setting up wherever we decide to camp out each day. Sometimes we stop at Porcupine Forest, other times Beaver Forest, the Lookout, the School Field, Rainbow Gulley, Moon Forest, Hidden Valley, and more. Wherever we go, a constant emerging invitation exists as we share stories in print, imagined, and orally. In this relationship, we learn about the multiplicity of who each of us is becoming as humans in the world. We engage in early literacy and numeracy with real world connections, empathy for each other and love, respect and care for what each of us is coming to know in our own time. Through our experiences we creatively embody personal and social responsibility, citizenship, identity, environment and community awareness, all parts of the mandated Alberta Education, (2011). Through this creative embodiment, we are assessment making, co-composing our days and in turn our lives in emergent meaningful, organic, and thoughtful ways. In this deeply connected process and relationship, each child, educator, and parent is able to think with our curriculum and discuss what we are each excelling at, working on, and nurturing through researching, studying, and practicing in hands-on experiential ways.

\section{REFLECTIVE PONDERING INWARD}

In coming to understand the possibilities of representing children's knowing and their learning as a dynamic process, with families and educators who are able to join in harmonious ways with care, kindness, and openness to what may or may not be, I am reminded about my own tree moment when I attended a conference in Oakland California.

Just prior to engaging in a Spring Independent Study Course with Drs. Janice Huber, Trudy Cardinal, and three MEd colleagues (who had long been part of my master's response community), I traveled to Oakland, California for the Children and Nature Network 2019 International Conference. This experience invited me to further consider who I am and who I am becoming alongside a long-time teaching colleague, Val. She invited me to travel with her and share our imaginings forward to 
help us collectively shift away from being complicit within school cultures, those that ooze dominant narratives and interlocking systems of harm which threaten to swallow our joy and seeking of possibility in community. Val and I had also collaborated with a dear friend for over a decade, Carol-Ann (no longer with us in body, but definitely in spirit), a teacher and my mentor, who was grounded in her beliefs of letting the children lead the way. I live by her words, "Here is my hand. Take it if you need it." As I have been alongside children, ever since Carol-Ann inspired me with her wisdom, I have heard time and again my own voice echoing those guiding words. I carry them with me and believe they invoke a shared sense of empowerment, bravery, and also security within the experiences I have with each learner I am alongside.

While at the conference, one of the sessions led us to a Redwood grove in the land of the Chochenyo-speaking Ohlone people. Afterwards, Val and I were lucky enough to linger with the session leader, not of Ohlone ancestry but one who deeply respects the people, land and stories, for dedicated time and space to get to know a tree. Inspired by our deep dialogue and experiences in the grove and during a quiet and reflective moment back in our hotel room, I wrote this letter:

\section{Dear Tree,}

Hello! I did not know you yesterday. Today I feel we have a connection. Thank you for beckoning me to be alongside you. For this I am truly grateful! Feeling engulfed with a fullness of gratitude, I want to linger. This day, our first meeting, I sense your invitation and reach for connection through mind, body, and spirit.

What does your spirit say? I feel it! It is patient and kind and allows me to venture up and down your trunk, with inquiry and wonder. My friend $\mathrm{Val}$ is with me. She, in spirit, carries our friend Carol-Ann too! We are alongside a new friend, our session leader. She teaches us to ask you for permission to feel, smell, and taste your presence.

We have been introduced to you in this place and as we use all of our senses you keenly invite us in. Thank you for your welcoming. My friends and I feel your smile. This moment in time matters to me! Did you know it would come some day? Did I? Why does that matter? Have we always been preparing for this uncertainty?

Always becoming, always in the making, always present to possibility,

Donna

In Oakland California, across a 5-day immersion and exploring storied moments like my own above, we, like Keith Basso (1996), noticed that "(our) perception of the tree has changed" (p. 120). In that moment, I felt inspired to wonder about the many "human events, consequential happenings, and memorable times" (p. 120) of all who have hugged this particular tree and her tree friends in this Redwood grove alongside Lake Merritt, adjacent to inland Lagoon on Ohlone Territory.
Upon my return to Edmonton and in dialogue with my response community, I shared this profound feeling of awakening to my connection with a tree in Oakland. In an environment of co-creating, my colleagues collectively agreed and wondered aloud, Donna, what if you change this "love letter" to read "Dear Child" instead of "Dear Tree?" I tried this. Immediately I began to notice the beautifully complex, plural ways we are in relation as living beings in the spaces we find ourselves in.

Dear Child, (I began) and as I read on, I could see how I was inspired by my deep connection to land and trees, and how I could truly begin to articulate that same strong connection to each child whom I am alongside. By writing Dear Child, I was able to acknowledge exactly how I feel when I first meet the young learners each year. Always, there is an invitation to be in relation with stories that have come before us and now invite open and caring connections. This letter, this invitation and its care, keeps me hoping that together we can grow a way forward on a journey across a school year and beyond, together.

\section{PAUSING ALONGSIDE THIS MOMENT ON A JOURNEY}

When I stop to think of the Tree Story in three parts, connecting it to assessment making as a way of considering what matters; why it matters; and considering how this knowing for now inspires us to move forward together, I think of the shared focus to learn and attend to our relations, with each other and the places and beings we engage with. I see it as an example of an ongoing invitation to assessment making with each child-individualized, personalized, and full of focus, intent, and meaning with room for emergent dips, turns and dives to other passions, interests, and wonders. Each storied tree moment in dialogue invokes curiosity and a different meaning for each child. A different learning journey each time. Together, we are co-curriculum making (Connelly and Clandinin, 1988) with intent, deciding to share our learning with children, educators, and families by moving forward with communication as a community. Today, I wonder about the continual possibilities to articulate the passion-driven knowing within each child, their family, and educators in Forest and Nature Kindergarten to further each of our collective knowings in emergent, honouring, joyful ways.

In Tree Story Part Three, I linger upon the details of how the child and his family came to dialogue about "his tree." What does that mean for him, his family, and me as an educator through the lens of an assessment making story? To delve deeply into this wonder and invite ways to make each child's learning increasingly visible for themselves, friends, family members, and co-educators, we spent time thinking alongside the story book Picture a Tree by Barbara Reid (2011). When asked to picture a tree by drawing it, the child in the Tree Story Part One was drawing hearts because, she announced, she loves hearts and "I love trees!" For further invitation, we read aloud Trees: A Poem by Harry Behn, illustrated by James Behn and Endicott, (1992). Each child, 
alongside their peers, was able to think with the words of the poem: "Trees are the kindest things I know" (p. 1). Guided by an invitation to write a letter to a tree, the child (in Tree Story $\sim$ Part One) selected a tree and began "Dear Tree." She stopped, smiled, and dictated, "I love that I can climb you." When asked what else she would like to say in her letter, she said she had said it all and signed her name with love. When I reflect on this moment as an educator and think forward to future invitations for learning to deepen and further each child's experience, I am seeking ways to open communication and joyful perspective-making with others. Through moments of shared read-alouds, wondering with each child, family members and educators, we may be able to collectively think backwards to the moments that may have led up to each child's passions and interests (in this case, to trees). Perhaps we may explore how further experiences in nature may ensue and strengthen each child's connection to what matters on our collective learning journeys in school.

This reflective story-thinking may become a way to support children to move confidently in their own ways of knowing, being, doing, and relating as they relay their thinking. What a beautiful, forward-looking imaginary this could be in life making and assessment making! Assessment making, which is internalized and embodied by each child-as open-armed, attentively listening, tree-climbing learners and knowers in the world. On this path, I am inspired to think further with these stories and openly imagine through each child's passionate learning and journeying, which will continue to emerge alongside our collective openness and becoming in the world.

\section{PUZZLING REFLECTIVE THREADS}

In the process of assessment making and participation, the autonomy of children's minds, along with their whole beings and identities being respected, honoured, and nurtured is of the utmost importance, as is their active engagement in their own becoming. As I yearn to make sense of assessment making in meaningful ways as an educator, I am seeking possibilities to articulate and invite families, educators, and administrators to embrace assessment making as a relational and ongoing uncovering through dialogue, a process of living. In my writing as a practicing teacher, reflecting on the theme of this special issue, I hope to have highlighted three resonant threads across my inquiring: Relationally Respecting; Dynamically Listening with Care; and Inviting Celebratory Journeying. I see these as important ways to think deeply and imaginatively alongside Mary Young's (2005) wisdom, shared with me as an introduction when I was a participant in the Winter 2019 Course at the University of Alberta called Assessment as Pimosayta Honouring Children: Indigenous and Relational Approaches,

"Like you said Aanung, "pimatisiwin, that is what it is all about." For you Niin, it is about being "a good person" and I respond by saying, "I am going to try to learn to walk in a good way." Both of you taught me that, and if we achieve that one small step towards all of us walking in a good way, both Anishinabe and non-Anishinabe, then we have accomplished something we didn't see at the beginning of our journey nor could we have even imagined. ... Kwa yuk ka kwe pimosayta. Let's walk in a good way. (italic in original, p. 179)

\section{Relationally Respecting}

Ermine (2015), Cree philosopher and educator, articulates the notion of "dancing particles," as a way to consider encountering energy and honouring movement as we journey in and through our "experiencing."” How we encounter each other matters! We feel another's aliveness and in turn, consider our own responsiveness as a way to actively animate another to act. Because of another's actions, we may send sparks of energy to the in-between-spaces of learning, growing, and relation. This sparking of energy invites a harmonious and joyful way of being in the world, as educators listen deeply to children and cherish their familial and community stories. With keen interest and energy reciprocating their relationship, travelling alongside with loving perception (Lugones, 1987), care and nurturing, and honouring creates the grounds for sparks to fly upwards and beyond in a playful dance of possibility! When children and educators run eagerly to learn more about an idea (as in Tree Story $\sim$ Part Two), then both are fully immersed and engaging in a collaborative and co-created learning moment, inspired and ignited by each other's familial and community stories that are deeply woven into their narrative beginnings. Anything is possible at that very moment as teaching, learning, relations go hand in hand.

\section{Dynamically Listening With Care}

Elder Gloria Laird, a Metis Elder who came alongside us during our Assessment as Pimosayta course, invited us to send light and love to the children whom we were alongside. I listened as she talked about her own Residential School experiences and in turn, intergenerational trauma. She emphasized how important it is to support children, and educators, to say the words, "Today I will love myself and tomorrow I will love myself even more.” Elder Gloria shared this wisdom to intentionally start each day with, in a place of peace and therefore, in support of children's abilities to feel calm and secure. She guided us to truly pause and listen to children. She told us to "allow children to teach you and open your heart to a totally different world view" (Teachings from Elder Gloria Laird, 2019). This reminded me of the importance of Noddings' (1986) work as she talks about genuinely enacting care for another. She refers to this as "natural caring - the sort of response made when we want to care for another" and how this way of being "establishes the ideal for ethical caring, and ethical caring imitates this idea in its efforts to institute, maintain, or reestablish natural caring" (p. 497). I am also reminded of Paley's (2015) presentation in which she talks about taking time as a teacher to record 
children's narratives, listening to children to support their ability to establish their identities in playful engaging ways. I aspire to this type of listening and sharing with parents through visual images, photographs, and learning stories, ${ }^{2}$ which involves pedagogical writing that upholds children's and families' voices/knowledge, further inviting familial and community narrative connections.

\section{Inviting Celebratory Journeying}

In conclusion, as I bring forward this final thread in reflection of my current puzzling for this special issue, I am drawn toward expressing my thinking with and alongside the teachings of Elder Stan Peltier, who also orally shared his teachings during my participation in the Assessment as Pimosayta course. He spoke to our classroom of educators about teaching as a dynamic journey: "Just as the Earth and Solar System are always in motion, we are always in continual motion" (Teaching from Elder Stan Peltier, January 2019). Elder Stan shared his knowledge of Seven Grandfather Teachings and provided permission for us to write about and teach these. As I aspire to internalize these teachings, the English words to represent each teaching remain present before me: Love, Respect, Honesty, Bravery, Humility, Truth and Wisdom. As I think with all three parts of the Tree Story, I see all these words resonate deeply within how I continue to interpret what I witnessed during those moments of teaching and learning. Questions jump forward as I consciously think and accept responsibility for nurturing and guiding young learners on a mutual journey. Together, we navigate what Elder Stan might suggest is "wisdom in holistic ways." Additionally, Elder Stan shared further teachings by describing the Anishinaabe word/concept of "Akinoonage," which means "to teach." In those moments, while at first sharing Anishinaabe words, I then concentrated on the English contextual interpretation of the words - "action," "animate," "acknowledg (ing) complexity," and "in the realm of all living things." For me, these words hold the spirit of emergence, ongoing creating, and learning. This spirit exists in the Tree Story, where the classroom community, inspired by familial learning, collectively shares and decides what to carry with them in their backpacks, wagons, and sleds as a way to continue to invite action-based experiential learning. Through our collaborative discussions of place, travel, exploration, and creative methods, based upon the complexity of varied children's passions and interests, experiences of deep growth were sowed. As I attend to Elder Stan's teachings, I think with this: "To teach is to direct the learner where to find knowledge, which can be or is to be understood according to their own intellectual acumen. The learner is NOT (said with emphasis) told, but has to reflect and arrive, hopefully to an individual personal perspective, or even a consensus type acknowledgement of perceived understanding" (Teaching from Elder Stan Peltier, 2019).

\footnotetext{
${ }^{2}$ CarrandLee (2012) in their writing and workshopping about learning stories make the connection between sociocultural approaches to pedagogy and assessment and narrative inquiry
}

In summary, for now, and thinking with my ongoing learning, I am inspired to continue to be ever present and available to all who I am alongside. Whether I am with a child, parent, co-educator, elder, knowledge keeper, professor, friend, and tree, I will endeavor to listen deeply and make spaces for emergence and possibility. While I continue to feel steady pressure to be accountable to larger institutional narratives as a way to demonstrate the "progress" of children, I will continue to seek wisdom from the children, their families and communities, the trees, the places we enter and share, and the unfolding emerging passions and interests of those who gather together on "school" landscapes. In this time, uncertainty is what we have and although it is vast and at times overwhelming, it invites imagination, creativity, and wonder. How exciting and joyful the unknown can be! What will happen today? What will happen tomorrow? Together we will discover next steps, inquiries, in depth learning and knowing as we sit with each other's stories and join in our emergent and collective thinking as a "school" community and beyond.

Roberta MacAdams Pure Joy Video 2021

\section{DATA AVAILABILITY STATEMENT}

The original contributions presented in the study are included in the article/Supplementary Material, further inquiries can be directed to the corresponding author.

\section{ETHICS STATEMENT}

Written informed consent was obtained from the individual(s), and minor(s)' legal guardian/next of kin, for the publication of any potentially identifiable images or data included in this article.

\section{AUTHOR CONTRIBUTIONS}

The author confirms being the sole contributor of this work and has approved it for publication.

\section{ACKNOWLEDGMENTS}

I am grateful to my University of Alberta Professors, Dr. Janice Huber and Dr. Trudy Cadinal for sharing the knowing of Assessment as Pimosayta (walking in a good way) (Young, 2005) and my Edmonton Public School Principal, Dr. Karen Keats Whelan for inviting assessment making that is lived out in relationally ethical ways on the school landscape where I am engaged in day to day teaching and learning as a Kindergarten Forest and Nature School Teacher

\section{SUPPLEMENTARY MATERIAL}

The Supplementary Material for this article can be found online at: Patel, Raj. [Orange Fountain]. (2021, March 11). Roberta MacAdams Teaser Pure Joy [Video]. YouTube. https://youtu.be/uw-qKv-b8Pg 


\section{REFERENCES}

Alberta Education (2011). Alberta Education Kindergarten Curriculum. Alberta: Alberta Education.

Basso, K. H. (1996). Wisdom Sits in Places: Landscape and Language Among Western Apache. Albuquerque: UNM Press.

Bateson, M. C. (1994). Peripheral Visions: Learning along the Way. New York: HarperCollins.

Behn, H., and Endicott, J. (1992). Trees: A Poem. New York: Henry Holt \& Company.

Caine, V., and Steeves, P. (2009). Imagining and Playfulness in Narrative Inquiry. Int. J. Educ. Arts 10 (25). Available at: http://www.ijea.org/v10n25/.

Cardinal, T., and Fenichel, S. (2017). "Indigenous Education, Relational Pedagogy, and Autobiographical Narrative Inquiry: A Reflective Journey of Teaching Teachers," in Crossroads of the Classroom (Bingley: Emerald Publishing Limited). doi:10.1108/s1479-368720160000028019

Carr, M., and Lee, W. (2012). Learning Stories: Constructing Learner Identities in Early Education. New York: Sage.

Clandinin, D. J., Caine, V., and Lessard, S. (2018). The Relational Ethics of Narrative Inquiry. Oxfordshire: Routledge.

Clandinin, D. J., and Connelly, F. M. (2000). Narrative Inquiry: Experience and story in Qualitative Research. Hoboken: Jossey-Bass.

Clandinin, D. J. (2013). Engaging in Narrative Inquiry. Walnut Creek: Left Coast Press, Inc.

Clandinin, D. J., Huber, J., and Murphy, M. S. (2011). Places of Curriculum Making: Narrative Inquiries into Children's Lives in Motion. Bingley: Emerald Group Publishing.

Connelly, F. M., and Clandinin, D. J. (2006). "Narrative Inquiry," in Handbook of Complementary Methods in Education Research. Editors J. Green, G. Camilli, and P. Elmore (Mahwah, NJ: Lawrence Erlbaum), 477-487.

Connelly, F. M., and Clandinin, D. J. (1988). Teachers as Curriculum Planners. Narratives of Experience. 1234 Amsterdam Ave., New York, NY 10027: Teachers College Press.

Dewey, J. (1938). Experience and Education. New York: Collier Books.

Greene, M. (1995). Releasing the Imagination: Essays on Education, the Arts, and Social Change. San Francisco: Jossey-Bass.

Huber, J., Caine, V., Huber, M., and Steeves, P. (2013). Narrative Inquiry as Pedagogy in Education. Rev. Res. Educ. 37 (1), 212-242. doi:10.3102/0091732x12458885
Ermine, W. (2016). "Intellectual Property Issues in Cultural Heritage," in Working Better Together Conference. [Video]. Youtube. Available at: https://youtu.be/ MIztZS7Nfo0.

Lugones, M. (1987). Playfulness, "World"-Travelling, and Loving Perception. Hypatia 2 (2), 3-19. doi:10.1111/j.1527-2001.1987.tb01062.x

MacLachlan, P. (1994). All the Places to Love. New York: Scholastic.

Murphy, M. S., Huber, J., and Clandinin, D. J. (2012). Narrative Inquiry into Two Worlds of Curriculum Making. LEARNing Landscapes 5 (2), 219-235. doi:10.36510/learnland.v5i2.562

Noddings, N. (1986). Fidelity in Teaching, Teacher Education, and Research for Teaching. Harv. Educ. Rev. 56 (4), 496-511. doi:10.17763/haer.56.4.34738r7783h58050

Nxumalo, F. (2015). "Forest Stories: Restorying Encounters with "Natural” Places in Early Childhood Education," in Unsettling the Colonial Places and Spaces of Early Childhood Education. Editors V. Pacini-Ketchabow and A. Taylor (Oxfordshire: Routledge), 31-52.

Paley, V. G. (2015). How Can We Study the Narrative of Play, when the Children Are Given So Little Time to Play. Chicago, Mar: Talk.

Reid, B. (2011). Picture a Tree. North Winds Press.

Young, M. (2005). Pimatisiwin: Walking in a Good Way: A Narrative Inquiry into Language as Identity. Pemmican.

Conflict of Interest: The author declares that the research was conducted in the absence of any commercial or financial relationships that could be construed as a potential conflict of interest.

Publisher's Note: All claims expressed in this article are solely those of the authors and do not necessarily represent those of their affiliated organizations, or those of the publisher, the editors and the reviewers. Any product that may be evaluated in this article, or claim that may be made by its manufacturer, is not guaranteed or endorsed by the publisher.

Copyright (C) 2022 Brown. This is an open-access article distributed under the terms of the Creative Commons Attribution License (CC BY). The use, distribution or reproduction in other forums is permitted, provided the original author(s) and the copyright owner(s) are credited and that the original publication in this journal is cited, in accordance with accepted academic practice. No use, distribution or reproduction is permitted which does not comply with these terms. 